\title{
Political Discussion on Social Media and the Public Sphere
}

\author{
Sarah Brenne \\ Independent based out of Selcuk, Turkey
}

Copyright $(2016$ by authors, all rights reserved. Authors agree that this article remains permanently open access under the terms of the Creative Commons Attribution License 4.0 International License

\begin{abstract}
The Internet is both a remediation and a cause of the destabilization of participatory democracy. This paper argues that social media fails as a functional public sphere; nevertheless, social media encourages civic engagement in nuanced ways. Social media imitates a structural public sphere; defined by Jurgen Habermas as an arena where citizens discuss public affairs. Social media fails as a public sphere because continuous surveillance and examination undermine public opinion. Instead social media succeeds through communicating political myths. Ronald Barthes defined political myths as cultural narratives that are encapsulated within an icon. In addition, using Kendall Walton's theory on mimesis, it is argued that political discourse online is experienced as a game with the use of icons. Previous research suggests a correlation between political discourse online and civic engagement offline; researchers continue to search for a causal relationship between political discourse on social media and attendance to civic engagement activities. In conclusion the culmination political myths, power, and mimesis drive social media users to participate in civic engagement activities. The Black Lives Matter movement following the killing of Michael Brown in 2014 in Ferguson, Missouri is used as a case study.
\end{abstract}

Keywords Social Media, Public Sphere, Civic Engagement, Political Myths

\section{Introduction}

On November 24, 2014 there were 40,000 social media posts with \#Ferguson within five minutes following the announcement that there would be no indictment for Ferguson police officer Darren Wilson in the shooting of unarmed African American teenager Michael Brown. This was a record breaking number of Tweets concerning a single, hot-button topic [1]. The shooting of Michael Brown raised concerns throughout United States about police use of excessive force directed at African American men. In the week leading up to the grand jury hearing over a million mentions of Ferguson were made on social networking sites nationwide and worldwide [1]. The story of Michael Brown became a rallying point for the Black Lives Matter movement. Racial inequality, expressed through police use of excessive force against African American men in the United States, became embodied in the hashtags \#Ferguson, \#handsupdontshoot and \#blacklivesmatter. Protests for Michael Brown accounted for just over a third of the nearly one thousand demonstrations on racial inequality worldwide in one year from mid-July 2014 to mid- July 2015 [2]. Ongoing research suggests a correlation between social media and attendance to protests [3], [4]. The Arab Spring in Tunisia and Egypt in 2011, Turkey's Taksim Square protests in Istanbul in the summer of 2013, and the nationwide protests on racial inequality in the United States; these events illustrate the increasing prevalence of social media use in political movements.

There are a variety of social networking sites, each with the same function: to share information. Friend based platforms, such as Facebook, Google+, LinkedIn, and Tumblr, where communication circles are based off of individuals' set of 'friends' or 'Followers.' These sites are primarily used for sharing photos or personal blurbs with a hyper-enlarged group of peers, friends and family. Twitter creates a news feed out of 'Tweets'- 140 character blurbs, with the capability of linking to other sources. Individuals choose to 'Follow' the authors of Tweets at which point they become a 'Follower.' Twitter is a common platform for organizing protests and sharing news clips [3]. Traditionally news sources work harmoniously with social networking sites. Newspapers, Television channels, and tabloids facilitate sharing news stories via social media with links and pre-scripted messages. The structure of social media as a platform for political discussion combines classic democratic values, such as the freedom of speech, with a new framework for political discussion.

There has been on ongoing, academic debate since the 1990s about the existence of a public sphere on the Internet, including social media [5]. The public sphere is a term coined by German philosopher and sociologist Jurgen Habermas in the 1960s. Habermas defined the public sphere as a theatre, distinct from the economy and the state, where political participation is acted through discourse [6]. Ideally, it is an arena for individuals to gather on an equal basis as a public to discuss issues relating to the common good. The 
public sphere is important for generating public opinion, which should not be influenced by the economy and which should influence government action. Public spheres are theoretically necessary to assess the functionality of participatory democratic governments. The question has been: Does political discussion on social media qualify social media as a viable public sphere?

The answer is two-fold. First, the qualifiers of the public sphere have changed in order to illustrate how social media could be $a$ public sphere [7]. Peter Dahlgren, Maria Bakardjieva, and Nick Couldry argued that new definitions of civic engagement and the public sphere should be used to evaluate political discussion on social media. Peter Dahlgren suggests that citizens are social agents with specific cultural factors behind their agency; this is Dahgren's concept of what he termed "civic cultures" to propose an alternative perspective to the significance of political discourse online. Dahlgren argues that meaning, identity, and subjectivity are important dimensions of online discussion, because they are essential attributes to political communication. Therefore, the fundamental practice on social networking sites of interaction and discussion between citizens lies at the forefront of an evolving public sphere [5]. Maria Bakardjieva argues that citizens use social media to make sense of political issues and that social media provides a platform for civic engagement activities in everyday life. Bakardjieva argues that "subactivism," or micro-communications, occur through everyday practices of citizenship on social networking sites [8]. These actions include reposting an article, sharing an original thought or feeling about a political issue, "liking" or sharing something that someone else has posted. Bakardjieva concludes that through participation on social networking sites, individuals will identify more with common values as well as the "common good." Finally, in a study by Nick Couldry et al., researchers recorded diary entries of social media participants and their involvement in civic engagement. $\mathrm{He}$ found that citizens feel they are engaged with a larger community when they contribute to an online community through social networking sites [9]. With new parameters for civic engagement and political discourse, previous scholars have argued that social media is a new form of Public Sphere. Social media does generate civic engagement; but does social media generate public opinion?

While social media creates a structural platform for a public sphere, political discussion on social media is subject to forms of power that inhibit what Habermas defined as public opinion. The commercialization of social media and a nuanced form of surveillance, on social media manufactures public opinion and creates a homogenous public. This second reading of political discourse on social media refutes the social media as a public sphere.

Social media mimics a public sphere in that it provides a platform for communicating ideas related to the public good; however it succeeds by communicating social narratives through icons [10]. Icons on social media are symbols with hashtags, images, or links to outside articles. These icons are not isolated; they represent narratives that provide significance to political circumstance. Political myths on social media are often historical events that represent a larger social narrative. Roland Barthes, a French literary theorist and philosopher, created a framework for identifying myths in contemporary society [10]. Political myths have increased exposure on social media; political myths now have unprecedented opportunities to become pervasive [11]. Citizens interpret political myths and engage with them as though a game of make believe [12]. Engaging with political myths on social media encourages participation in civic engagement activities, such as attendance to Black Lives Matter protests. Kendall Walton's theories on mimesis and game theory create this vital link from political discourse on social media to participation in civic engagement activities offline.

Habermas's model of the public sphere is useful to understand the structure of political discussion on social media [9]. However, social media fails as a formal public sphere [13]. Instead, social media mimics the structure of a public sphere and succeeds in communicating political myths through icons. Mimesis, identifies parallels between political discourse on social media to experiencing a play, a novel, or a film. Therefore, political discussion on social media does directly influence civic engagement in political movements, though not through candid political discourse.

\section{Social Media as a False Public Sphere: How Political Discussion on Social Media Leads to Protests}

Public spheres are communicative spaces where information and ideas circulate; a public sphere is a space where private persons come together to discuss the common good and to formulate public opinion [6]. Three dimensions are fundamental to conceptualizing the public sphere in relation to online discussion [5]. The first dimensions are the structural and representational features. This dimension focuses on classic democratic rights such as the freedom of speech and equal access to a public sphere. The representational dimension considers the output of symbolsphrases, signs, or images- and their communication. The third dimension of the public sphere is the interactional dimension. Habermas argued that the public sphere should include discursive interactional processes. The interactional dimension is two-fold. Citizens first encounter pieces of media, then there is the communicative process of interpreting the output; and second, citizens engage in discussion about the output between themselves. These three dimensions provide an analytical framework for examining the public sphere in relation to the Internet and social media [5].

Social media formally has these three structural features. Social media is a platform that allows equal accessibility. 
Social networking sites are free to use and to sign up for. Furthermore, WiFi hotspots and Internet access through cell phones has made social media accessible. For example, during the Tunisian uprising and the ensuing Arab Spring, around ninety percent of the population had access to social networking sites through either the Internet or cell phones [3]. Social media also offers freedom of speech, furthermore providing an audience. The second dimension, the output of symbols, images or signs is the very foundation of social media; sites which are designed to share symbols. Finally, social media users are able to encounter media, interpret the output, and engage in discussion instantaneously. While previous forms of communication were discussed in terms of "one to one," personal communication, or "one to many," which is typical of mass media. Social media has attributes of both mass communication and personal interaction. This is integral to the interactional aspect of the public sphere that social media strongly supports [5]. These three indications suggest that social media provides a framework that enables a public sphere.

Additionally, Habermas emphasizes two criteria that allowed for the rise of the public sphere in the $17^{\text {th }}$ and $18^{\text {th }}$ centuries in continental Europe. The first condition was the rise of the reading public. The bourgeoisie would meet in coffee houses to critically discuss literature [6]. The rise of a reading public resulted in an array of popular literature critiquing the regimes of the $18^{\text {th }}$ century [14]. The second condition was the rise of private spheres, specifically freedom of religion and land ownership. The bourgeois public sphere that Habermas uses as a model arose under these initial circumstances, but remains a common framework for assessing a functional deliberative democracy. Can a new public sphere be reconstructed under different socio-economic, cultural and political conditions? And with the Internet as a new medium?

The structure of the public sphere and the conditions for the rise of a public sphere are parallel with the rise of political discussion on social media. It would appear that social media as a functional public sphere is based on geopolitical circumstance. Under oppressive regimes with limited rights and censored news outlets, social media allows each citizen the equal access to a public sphere that is denied to them by their government. In the Tunisian uprising and the ensuing Arab Spring around ninety percent of the population had access to social networking sites, if not through the Internet then through their cell phones. In addition, women had the opportunity to engage in political discourse in countries where they had previously been discouraged from engaging in public debate [3]. In junction with more access to social media is the rise of an informed and reading public. The Internet has provided unlimited access to information and news. This parallels some of the ways in which continental Europe excelled with a larger reading public. For instance, the underground book trade in pre-Revolutionary France featured porn, fantasy, and slander which were often dismissed as being unrelated to the ensuing revolution and rise of a democratic government. However, the popular literature illustrated seeds of discontent in pre-Revolutionary France and informed the public to alternatives [14]. The circumstances for the rise of Habermas's public sphere in bourgeois coffee houses parallels the appearance of social media in providing a platform for debate among citizens, access to a winder body of knowledge, equal access to participation and freedom of speech.

Social media fails as a public sphere in Habermas's terms. Habermas described the downfall of the public sphere as being connected to the mediatization of politics and the commercialization of the media [6]. The mediatization of politics on social media creates a cynical public body [15]. On social media, where everyone is their own media outlet, there is a cacophony of actors and mediators [5]. Instead of critical debate, participants share supporting articles with friends of the same opinions and different spheres form that rarely consider the opposing viewpoint. Social media is a commercial platform. On Facebook, for example, users' news threads are interspersed with advertisements that have been cleverly crafted for each user using data that includes everything from age, relationship status, interests, messages, comments, likes, and browser history. Social media is an extension of what Habermas described as the reason for the downfall of the public sphere: the mediatization of politics and the commercialization of the media.

Habermas also argued that public opinion deteriorated as the public sphere became intertwined with the economy. When the bourgeoisie began to use the coffee shop for economic affairs the public sphere waned as an idyllic form of participatory democracy. Social networking sites such as Facebook or Twitter have become platforms for advertisements and have been incorporated. Creating an environment that does not allow for genuine political discourse. Finally, Habermas claimed that the public sphere became a platform for promoting consumer culture. Social media is used to promote a consumer culture. Psychologically social media drives users to promoting a style or brand of themselves and companies use this data to sell more products.

Furthermore, Habermas argues that the public sphere became a utility for managing consensus and less a space for public information and for debate [6]. Social media has become a tool for managing consensus through continuous surveillance and examination, two terms defined by Michel Foucault. Foucault's panopticon thesis argues that surveillance is a mechanism of power. Periodic yet unpredictable surveillance creates a conscious state of permanent visibility [16]. In a conscious state of permanent visibility power functions automatically. The same utilitarian purposes are applied to social networking sites where the users' profiles are structured to make differences visible and the participant is aware of constant surveillance [16]. Interestingly, social media has a phenomenon that distinguishes it from Foucault's panopticon. Notably, surveillance operates on social networking sites through desired visibility and a threat of invisibility [16] [17]. Social networking sites are designed such that visibility is perceived 
to be scarce and therefore desirable [16]. Social media is designed around sharing and receiving desired attention. Surveillance and examination filter and reward discussion on social networking sites through the citizens' desire for attention. Therefore, social media operates not as a public sphere for candid political discussion, but instead social media operates as a platform that manages consensus through forms of power. Using Habermas's models for both the rise of a public sphere and its decline, it is clear that social media fails as a functional public sphere.

Nevertheless, social media mimics a public sphere. Social networking sites have two fundamental differences from the bourgeois coffee houses defined as the public sphere by Habermas. The first is obvious: a coffee shop is a physical space while the Internet is in virtual space. This has less obvious consequences. The most important is that on social media each person has the ability to be their own media outlet, as Lee Rainie and Barry Wellman argue in Networked [18]. The result is in the process between representation and interaction; social media users create media output as they consume the media themselves [5]. Therefore the communication process of the public sphere is no longer a linear or even circular transaction. This leads to the second key difference: the production of messages. Stuart Hall, a cultural theorist, proposed a circular stage theory to describe the way in which messages are produced, circulated, distributed, consumed, and reproduced through televised mass media [19]. On social networking sites the stage theory is no longer circular; the production of messages is more of a convoluted web [20]. Therefore messages on social networking sites are produced, circulated and consumed simultaneously. Social media is able to spread messages about a Black Lives Matter protest faster than traditional news outlets. These differences influence the interactional dimension of the public sphere. Citizens encounter and interpret news in real time and can engage in discussion immediately.

Social media produces messages or fragments that encourage civic engagement, especially in the form of protests or demonstrations. The use of images, icons, GIFs and symbols make claims to truth on social media, defined as fragmentary references. Fragmentary references refer to larger narratives, and as the references become more pervasive, the narratives become interpreted as claims to truth. Social media has an unprecedented ability to spread fragmentary references. With an increase in messages as well as an increase of sources, fragmentary references have a greater likelihood to be interpreted in ways that are further from the messages intended meaning [21]. Therefore, the reliance on fragmentary references creates an unwieldy source for information. Fragments refer to political myths, large social narratives.

Political myths are the continual production and reproduction of a common narrative used by citizens to ascribe significance to political circumstance [11]. Common narratives arise from historic events. The 'myth' is the narrative used to explain the event. In discussing myths there are no claims to truth or to fiction. The focus is on narratives that shape and reshape political discourse. Hans Blumenberg defined myths as the continual "work" on a narrative core [22]. Blumenberg argues that the work on myth arises out of the human need to ascribe significance to inexplicable circumstance. The production, reception, and reproduction of a narrative constitute the "work on myth." Myths become political as they reproduce significance and address political conditions [11]. Political myths are "worked on" through cumulative exposure to the work on them, through speeches, art, community gatherings, and social practices. Myths are condensed into "icons," which are interpreted by citizens as narratives that appear to be fixed or natural [10]. All forms of media are a platform for the production, reproduction and reception of icons. Icons are economical yet influential because they are small, but communicate narratives that create significance for citizens. Political myths are not simply what we perceive about politics, but also the lenses through which we perceive politics.

Roland Barthes, author of Mythologies, a catalogue of modern day myths, defines myths as a meta-language adapted from Saussure's theory of linguistics. Language is composed of a signifier and a signified which create a sign. A signifier is the word used to describe a thing, while the signified is the thing itself. Therefore, language is a series of signs that denote reality. Barthes uses this foundation to argue that with myths, the linguistic sign becomes the signifier plus a new signified, creating a new "meta" sign. The new sign conveys the myth.

The language used on social media follows this framework. For example, the hashtag \#handsupdontshoot was commonly used on social networking sites in relation to the death of Michael Brown. The signified, a young, unarmed, African American male shot by a white police officer; and the signifier, "Hands up, don't shoot," create a sign. The sign is the excess use of force against African American males by police officers, a result of a long history of racial oppression. The fragmentary reference, "Hands up, don't shoot," packs a history racial oppression from the foundation of the United States into seventeen characters. Even after the court determined that Brown's hands were not above his head when Officer Wilson shot him, "Hands Up, Don't Shoot" remained a rallying cry of a movement created to draw attention to racial inequality in the United States. Therefore the fragmentary reference, one example of racial oppression, is able to communicate a narrative that is interpreted by the citizen in the form of a myth.

Political myths, spread through social media, are influential in the non-virtual sphere. Despite these drawbacks, it is the interpretation of political myths that lead citizens who participate in political discussion on social media, a virtual platform, to physically attend civic engagement activities. How can a political myth create civic engagement in the form of protests such as the Black Lives Matter movement? I argue that we experience political discussion on social media, in the form of political myths, in 
the same way we experience fictional narratives, art or theatre, we are lead to participate in civic engagement activities.

Social media operates as a stage for communicating political myths, as opposed to a stage for candid political discussion, or a public sphere. Using Kendall Walton's theory on Mimesis, I argue that political discussion on social networking sites can be re-conceptualized as an interactive game of make-believe to create the link between political discussion on social media and civic engagement [12]. Participants, spectators, props, and a stage create a virtual experience of art or fiction that can transfer emotions to "real life." Participants contribute to a political discussion through blogging, commenting, and sharing articles of relevance to the community or group. Props can be anything from the articles that are linked through URL's to personal opinions shared in posts. Spectators read into a discussion, in comment feeds or group discussions. More importantly, the participants are acting with the knowledge of being watched by faceless thousands. The stage is social networking sites, and the webs of communication that occur on these sites [20]. The conventions governing the game are that participants must go along with the claims to truth. Imagine a card game where players do not follow the rules: this removes both the fun of the game as well as its purpose. This is similar to how participants engage on social media; there are claims to truth, and in order to contribute to the discourse, one must acknowledge that previous participants have made legitimate claims to truth in order to rebuke or highlight those claims. Mimesis explains how political discussions in the virtual sphere lead to large scale protests.

\#Ferguson, \#blacklivesmatter, and \#handsupdontshoot do not embody the problem of racial discrimination in the United States. For instance, someone may Tweet about an incident that incurs feelings of prejudice and include any one of these hashtags as a symbol for systemic racism nationwide. Moreover, attendance to protests was rallied through social networking sites, indicating that participants and spectators of online discussion take the claims made through social media seriously [4]. A specific example is of the two main organizers for the protests in Ferguson following the grand jury hearing. Together they reached over 20,000 followers. One of them tweeted: "We protest because we know that we will get killed if we are silent and the risks of speaking are worth it. We protest to live. \#Ferguson" [23]. From \#Ferguson it is understood that there is another layer to his claim. It is understood that the "we" is the African American community; and the "we will get killed" is reference to the expression of racism in the United States where $40 \%$ of the victims of homicides are African American men, a minority that makes up $6 \%$ of the whole population [24]. The hashtag, \#Ferguson, is emblematic for racial discrimination in the United States. Therefore a reading of this tweet culminates a social narrative into a 140 character text through an icon.

Similar to the how we watch a film or read a novel; one generates a mental experience in relation to the narrative purported by topics discussed on social media. Walton argues that while we do not relive the emotions from the fictional world when we see a film or read a novel, we do experience a quasi-emotional overlapping of the depicted emotion [12]. Therefore, we use a dual consciousness to appreciate games of make believe: one that can go along with fictional worlds, and the other that generates our responses to the fictional world. For instance, if a father plays a monster with his child, the child recognizes that it is a game of make believe and appreciates their role of running away in mock fear. The child is experiencing the quasi-emotion of fear, but is also experiencing joy at the game [25]. As individuals we find gratification in games of make-believe when the separate spheres of consciousness cooperate. This mental and internal experience is similar to engaging in or viewing political discourse on social networking sites.

There is a quasi-overlapping of emotion through social networking sites. Participants can appreciate games of make believe with an "avatar" that engages in political discourse on social networking sites. However, engaging in social media generates changes outside of the virtual world [21]. This is exemplified with the turnout to protests that are in part inspired by the dispersion of information through social networking sites [2] [4], [26]. Racism in America is often ambiguous and often denied. Political movements need narrative to make use of icons and signs in order to encourage political action [27].

\section{Conclusions}

Social media does provide a formally equal platform, or a stage, for engaging in political discourse in accordance with the structural features of a Habermasian public sphere. There are clear caveats to social media as a platform for candid political discussion. Nevertheless, social media remains a popular platform for organizing political movements. I suggest that the impact of social media arises from the ability to spread icons that represent political myths. Furthermore, that political myths and discourse on social media are experienced in accordance with how we experience fiction in art and theatre. I propose that this perspective could allow for citizens to recognize their participation in a game when engaging in political discourse online; this perspective would allow for participates to engage mindfully with social media and recognize that it is one minor tool for enacting political change.

The ways in which we experience these myths is fundamental to political action movements such as Black Lives Matter. I predict that political action similar to these movements will become closer to the norm. These movements create hyper-sensitivity to political problems for a brief amount of time although what is being communicated through social media references systemic problems. The alleviation of the political injustices that each of these movements have protested have not been successful. It is clear that social media works as a stage for political discourse, but the long term effects have not proven to be liberating. 


\section{Acknowledgements}

I am grateful to Dr. Olaf Tas of Amsterdam University College and Dr. Andre Lambelet of Quest University Canada.

\section{REFERENCES}

[1] L. Lohuis, "Social Media Listening lab sees record posts on Ferguson," WYFF4, 25-Nov-2015.

[2] A. Robinson, "At least 957 Black Lives Matter demonstrations have been held in the last 358 days." Elephrame, 04-Jul-2015. [Online]. Available: https://elephr ame.com/textbook/protests. [Accessed: 12-Jul-2015].

[3] P. N. H. and A. D. and D. F. and M. H. and W. M. and M. Mazaid, "Opening Closed Regimes: What Was the Role of Social Media during the Arab Spring?" 2011.

[4] J. Tucker, "Tweeting Ferguson: how social media can (and cannot) facilitate protest," The Washington Post, 25-Nov-2014.

[5] P. Dahlgren, "The Internet, Public Spheres, and Political Communication: Dispersion and Deliberation," Political Communication, vol. 22, no. 2, pp. 147-162, Apr. 2005.

[6] J. Habermas, The Structural Transformation of the Public Sphere. Cambridge: The MIT Press, 1989.

[7] N. Fraser, "Rethinking the Public Sphere: A Contribution to the Critique of Actually Existing Democracy," Social Text, no. 25/26, pp. 56-80, Jan. 1990.

[8] M. Bakardjieva, "Subactivism: Lifeworld and Politics in the Age of the Internet," The Information Society, vol. 25, no. 2, pp. 91-104, Mar. 2009.

[9] N. Couldry, S. Livingstone, and T. Markham, "Connection or disconnection? Tracking the mediated public sphere in everyday life," in Media and Public Spheres, R. Butsch, Ed. Basingstoke, UK: Palgrave Macmillan, 2007, pp. 28-42.

[10] R. Barthes, Mythologies. New York: Hill and Wang, 1957.

[11] C. Bottici and B. Challand, "Rethinking Political Myth The Clash of Civilizations as a Self-Fulfilling Prophecy," European Journal of Social Theory, vol. 9, no. 3, pp. 315336, Aug. 2006.
[12] K. Walton, Mimesis as Make-Believe: On the foundations of the representational arts. Cambridge, Mass.: Harvard University Press, 1990.

[13] M. Foucault, Discipline \& Punish: The Birth of the Prison. New York: Random House, 1977.

[14] R. Darnton, The Forbidden Best-Sellers of Pre-Revolutionary France. New York: Norton and Company, 1996.

[15] B. Olivier, "Facebook, cyberspace, and identity," Psychology in Society, no. 41, pp. 40-58, Jan. 2011.

[16] T. Bucher, "Want to be on the top? Algorithmic power and the threat of invisibility on Facebook," New Media Society, vol. 14, no. 7, pp. 1164-1180, Nov. 2012.

[17] D. Fletcher, "How Facebook Is Redefining Privacy," Time, 20-May-2010.

[18] L. Rainie and B. Wellman, Networked: The New Social Operating System. Cambridge: MIT Press, 2014.

[19] S. Hall, "Encoding, Decoding," in the Cultural Studies Reader, New York: Routledge, 2007.

[20] L. Rainie, A. Smith, K. L. Schlozman, H. Brady, and S. Verba, "Social Media and Political Engagement," Pew Research Center's Internet \& American Life Project, 19-Oct-2012.

[21] J. Ronson, "How One Stupid Tweet Blew Up Justine Sacco's Life," The New York Times, 12-Feb-2015.

[22] H. Blumenberg, Work on Myth. Cambridge, Mass.: MIT Press, 1985.

[23] R. M. Fillion, "How Ferguson Protesters Use Social Media to Organize," 24-Nov-2014.

[24] J. Leovy, Ghettoside: A True Story of Murder in America, Reprint edition. Spiegel \& Grau, 2015.

[25] O. Tans, "The imaginary foundation of legal systems - a mimetic perspective," Law and Society Review, pp. 127-143, 2014.

[26] "There have been 778 Black Lives Matter demonstrations in the last 239 days." Elephrame. [Online]. Available: https://www.elephrame.com/textbook/protests. [Accessed: 15-Mar-2015].

[27] H. L. J. Gates, The Signifying Monkey: A Theory of African-American Literary Criticism. New York: Oxford University Press, 1998. 